Costs of all Projects are worked out on a unit basis, that is, so much per lineal mile for Land Survey lines, square mile of Forest Surveys, miles of Roads of various classes, complete Administrative sites, miles of metallic telephone line, acres of thinning in various age classes and species, etc.

The above will give you an idea of our Forestry Plan to date. We are, of course, continually making adjustments, particularly as to specifications and costs.

I should point out that while the Manitoba Government is very much interested in Post-War planning, no commitments have been made as yet as to how money will be spent.

\title{
OUTLINE OF POST-WAR FORESTRY PROGRAM IN SASKATCHEWAN
}

By E. H. RoberTs

Director of Forests, Regina, Saskatchewan.

$\mathrm{T}$

HE SASKATCHEWAN Reconstruction Council Act of 1943 was passed early in that year followed by the appointment by Order in Council of a chairman, six members and a secretary to study and investigate conditions and problems that are likely to arise during and after the conclusion of the war, to consider, develop and recommend plans, policies and activities for the purpose of meeting such conditions and problems and to submit reports and recommendations to the Lieutenant Governor in Council.

The Council was authorized to confer with federal, provincial and municipal authorities, operators of industries, agriculturists, organizations of em. ployers and of employees and any other bodies and have the powers of investigation conferred by the Public Inquiries Act and make regulations for the carrying out of the provisions of the Act.

Members of the Council consist of representatives of industry, labour, merchants, agriculture, the Canadian Legion and women's organizations. The Council held meetings and hearings at numerous points in the province and has received numerous reports, plans and recommendations from gov. ernment departments, organizations and individuals.

A Forestry Reconstruction Works Program under the heading of Forest Fire Prevention and Protection, Silvicultural Development and Resorts and Recreation was prepared in detail by the Department of Natural Resources of the Provincial Government aimed at employing 1,000 men or more annually for a period of five years with approximately one and one half million man days, subject to expansion or contraction as circumstances may warrant.

The objects in view are an enlarged forest fire protection organization, extension of fireguards, forest roads and trails to make the timbered areas more accessible for extraction of forest products and for fire suppression purposes. The construction of small dams for water conservation and the development of muskrat lease areas are proposed together with the removal of fire hazards. 
Forest stand improvements by thinnings, cleanings and the removal of parasite infected timber are proposed on extensive areas of valuable young and immature timber. Expansion and development of forest nurseries is contemplated for the purpose of supplying planting stock to reforest barren and burned over accessible areas that can be given reasonably adequate protection from fire. Resort and recreational areas in provincial parks and in forest areas accessible to the local population will be developed for the use and enjoyment of those citizens residing on the treeless plains regions for the purpose of restoring health and maintaining morale.

Other branches of the Department of Natural Resources have recommended reconstruction plans for the development and improvement of game and fur resources, fisheries and for prospecting and developing of mineral resources.

All of the forestry plans may be executed in coroperation with the Dominion Forest Service and the completion of the National Forest Inventory in this province is anticipated by further aerial mapping. Continuation of the forest insect survey on a broader scale and studies of insect damage and control are necessary for proper forest management. Forest research and study of tree diseases in co-operation with Dominion authorities are contemplated on a much larger scale than has been possible in the past.

It is anticipated that, with the completion of the plans and work sug. gested, the forests may be placed in a more productive condition to supply local needs with a surplus of forest products for export.

\section{POST-WAR RECONSTRUCTION PLANS IN ALBERTA \\ By T. F. BLEFGEN \\ Director of Forestry, Edmonton, Alta.}

N REGARD to Post.War Reconstruction in Alberta, this is still in the formative stage and although a number of committees have been set up under the chairmanship of the Honourable N. E. Tanner, Minister of Lands and Mines, reports have not yet been made and it is very doubtful if they will be made or that they will be available prior to the next sitting of the Legislature, which I understand will be some time in February.

Numerous committees have been set up in the Province and as a matter of fact almost every city, town and village has set up such a committee and they are now working on their reports which perhaps will be eventually compiled into an interim and then a final report.

You can readily see from the above that even were I able to attend the Annual Meeting, we are not yet in a position to deliver a report that would be at all enlightening. Furthermore, we have made certain submissions to the Dominion Government and are busy co-operating with the committee working on natural resources and conservation but this report when ready will be submitted to the Honourable N. E. Tanner and it would certainly not be in order for me to divulge the contents of the part we are working on prior to this being made known by the Minister. 